This item was submitted to Loughborough's Research Repository by the author.

Items in Figshare are protected by copyright, with all rights reserved, unless otherwise indicated.

\title{
Fashioning Michael Field: Michael Field and late-Victorian dress culture
}

\section{PLEASE CITE THE PUBLISHED VERSION}

http://dx.doi.org/10.1080/13555502.2013.783413

\section{PUBLISHER}

(C) Taylor \& Francis

\section{VERSION}

AM (Accepted Manuscript)

\section{PUBLISHER STATEMENT}

This work is made available according to the conditions of the Creative Commons Attribution-NonCommercialNoDerivatives 4.0 International (CC BY-NC-ND 4.0) licence. Full details of this licence are available at: https://creativecommons.org/licenses/by-nc-nd/4.0/

\section{LICENCE}

CC BY-NC-ND 4.0

\section{REPOSITORY RECORD}

Parker, Sarah L.. 2019. "Fashioning Michael Field: Michael Field and Late-victorian Dress Culture". figshare. https://hdl.handle.net/2134/22654. 


\title{
Fashioning Michael Field:
}

\section{Michael Field and Late-Victorian Dress Culture}

\author{
Sarab Parker
}

Katharine Bradley (1846-1914) and Edith Cooper (1862-1913) have become increasingly well known as important fin-de-siècle poets who published collaborative lyrics and verse dramas under the shared pseudonym of 'Michael Field'. Aunt and niece, they dedicated themselves to a life-long partnership that was both romantic and creatively productive, beginning with Callirhoë, published in 1884 - the first work to be published under their collaborative male pseudonym. In her brief biography, We Are Michael Field (1998), Emma Donoghue remarks that the two women were 'equally interested in feminine clothes and masculine nicknames'. ${ }^{1}$ In the growing body of critical work on Michael Field, scholars have tended to focus exclusively on the latter. However, in the present article, I turn the critical spotlight onto the former: the significance of Bradley and Cooper's interest in feminine gowns, hats and jewellery. I propose that Bradley and Cooper's passionate engagement with late-Victorian dress culture represents a hitherto overlooked dimension of their carefully constructed poetic identity as aesthetic writers. ${ }^{2}$ In tandem with the 'masculine' pseudonym that has attracted so much critical discussion, the donning of feminine gowns and the deliberate cultivation of an aesthetic sartorial style was a distinctively 'feminine' way in which Bradley and Cooper participated in the aesthetic movement. Moreover, fashion played a key role in mediating Bradley and Cooper's homoerotic intimacy.

\footnotetext{
${ }^{1}$ Emma Donoghue, We Are Michael Field (Bath: Absolute Press, 1998), p. 31.

${ }^{2}$ In addition to the present article, this neglect is soon to rectified by Ana Parejo Vadillo's chapter 'Living Art: Michael Field, Aestheticism and Dress' in the forthcoming essay collection Crafting the Woman Professional in the Long Nineteenth Century: Artistry and Industry in Britain, eds. Kyriaki Hadjiafxendi and Patricia Zakreski (Farnham, Surrey and Burlington, Vermont: Ashgate, 2013).
} 
Frequently, when they tried on new dresses and exchanged hats and jewellery as gifts, these coauthors were inspired to write poems in praise of each other's beauty. Thus, in a number of different ways, fashion played a key role in reconciling the separation between the public identity of 'Michael Field' and the private world of Bradley and Cooper.

Focussing on Bradley and Cooper's gowns brings a vital tangibility to Michael Field, which can help us to understand the relationship between their private and public identities. Of course, their expensively bound published volumes are indeed tangible, bearing testament to their public identity as aesthetic writers publishing collaboratively under a male pseudonym. But in critical studies of their work, their lives as two women have often been viewed as obscured by this male pseudonym - as a private life to be uncovered, in order to unearth an authentic female (and lesbian) identity: the supposedly secret feminine side of Michael Field. However, I propose that concentrating on Bradley and Cooper's dress in fact deconstructs (rather than reinforces) these fixed notions of the public/masculine or the feminine/private. I argue that Bradley and Cooper's feminine clothing was performative — playing a vital part in Bradley and Cooper's participation in aestheticism. In this sense, Bradley and Cooper's clothing, like the thirty volumes of journals they collected under the title of 'Works and Days', traverses the division between public performance and private expression.

The first section of this essay sets Michael Field firmly in the context of fin-de-siècle dress culture. I look at actual diary accounts of what the poets, and their friends and acquaintances, were wearing. These descriptions are numerous and incredibly detailed, and frequently combine with similarly intricate descriptions of décor, flowers and book-covers. In this sense, Bradley and Cooper's interest in fashion clearly chimes with their embeddedness in aestheticism. As Talia Schaffer notes, home decoration and fashion were two arenas in which women asserted their own claim to be aesthetic in the late Victorian period: 
For the aesthetes who attempted to introduce beauty into everyday life, British dress was an obvious target for reform. Dress, they felt, should be art, not fashion. [...] Although Wilde was the most visible of the aesthetic fashion reformers, women actually wrote most of the aesthetic fashion manuals. These female aesthetes claimed that they had made clothing into art, and they displayed the elite education associated with the connoisseur. $^{3}$

Michael Field's utilization of aesthetic fabrics and fashions alongside their literary aestheticism also bears out Christine Bayles Kortsch's argument that late-Victorian women experienced a 'dual literacy' in words and fabric. ${ }^{4}$ Kortsch observes that Victorian girls were simultaneously educated in the skills of sewing and reading as part of their rudimentary curriculum. For example, they were taught to read the pattern of stitches that made up a gown, or to learn the alphabet by stitching a sampler. Thus, whether they were working-class women who darned socks or upperclass women who undertook fancy work, Victorian women learned to 'interpret the social significance of cloth' 5

Kortsch's notion of 'dual literacy' is highly pertinent to late-Victorian aesthetic culture's frequent reading of clothes and dressing of literature in general — and to Michael Field in particular. Whereas Kortsch's study explores how New Women writers dressed their protagonists, I focus on what Bradley and Cooper chose to wear. Bradley and Cooper's beautiful gowns, hats and jewellery, alongside their pseudonym, provided a different yet complementary

\footnotetext{
${ }^{3}$ Talia Schaffer, The Forgotten Female Aesthetes: Literary Culture in Late-Victorian England (Charlottesville: University Press of Virginia, 2000), p. 103.

${ }^{4}$ Christine Bayles Kortsch, Dress Culture in Late-Victorian Women's Fiction: Literacy, Textiles, and Activism (Farnham, Surrey and Burlington, Vermont: Ashgate, 2009), p. 4.

${ }^{5}$ Kortsch, Dress, p. 9.
} 
way of constructing their poetic identity, one highly in keeping with their wider aesthetic strategies and desire for each other.

\section{Artistic Dress: Michael Field and Late-Victorian Fashion}

Many scholars have observed that during the latter half of the nineteenth century women's dress was in the process of radical transformation, with principles of health and aesthetics at the heart of the new reform movements. In the earlier part of the century, as Stella Mary Newton has commented, with the brief exception of the 'Directoire' or empire style of the early 1800s, the fashion of the 1840s and 1850s was incredibly restrictive:

partly because it was laced very tightly around the ribs, partly because of the number of petticoats that were necessary to build the skirt out to the required bell-shape, but above all because the sleeve was set, not on the top of shoulder but into a line two or three inches below it, on the upper arm. ${ }^{6}$

By the 1860s, members of the Pre-Raphaelite movement recognized the need to reform women's dress, drawing on earlier styles from medieval, Renaissance and Ancient Greek art. Dante Gabriel Rossetti, for example, copied close-fitting fourteenth-century styles, believing that contemporary styles created what Patricia A. Cunningham states was thought to be 'unnatural' female silhouette. ${ }^{7}$ This new 'Artistic' dress for women, as Edwina Ehrman notes, was characterized by the wearing of flowing, gathered or draped gowns: 'simple dresses in plain

\footnotetext{
${ }^{6}$ Stella Mary Newton, Health, Art \& Reason: Dress Reformers of the Nineteenth Century (London: John Murray, 1974), p. 31.

7 Patricia A. Cunningham, Reforming Women's Fashion, 1850-1920: Politics, Health and Art (Kent, Ohio: Kent State University Press, 2003), p. 106.
} 
fabrics draped from the shoulders, with unconstricted waists and sleeves that did not inhibit movement'. Artistic dress eschewed the artificial 'enhancements' of the bustle or corset, in favour of a looser, more comfortable silhouette, based on medieval-style gowns. Such gowns featured large, puffed sleeves and smocking at the waist, wrists and neckline, to emphasise the natural lines of the body. In addition to medieval or Renaissance-inflected styles, shapes also took inspiration from supposedly exotic cultures such as Ancient Greece and the East, with kimonos and Indian pyjamas growing in popularity. Favoured fabrics included wool, silk and velvet, usually decorated with artistic designs, including flowers (such as sunflowers) or peacock feathers. ${ }^{9}$ Hand-embroidery of such designs was preferred, as a reaction to the sewing machine, and vegetable dyes were preferred to synthetics, which were seen as too garish and artificial to be truly beautiful, following John Ruskin's pronouncement that: 'No colour harmony is of a high order unless it involve indescribable tints'. ${ }^{10}$ This trend led the aesthetic fashion critic Mary Eliza Haweis to pronounce: 'No artistic colours are unduly bright; they are all more or less dull'. ${ }^{11}$ These details, according to Kortsch, 'reflected the philosophical origins of artistic dress', which valued 'the handmade over the machine-made, the one-of-a-kind over the mass-produced'. ${ }^{12}$

Despite the Pre-Raphaelites' efforts to reform dress, however, most fashionable styles of the 1870 s and 1880 s still required a tight corset. The bustle had replaced the crinoline, so the skirt was now snugly fitted around the legs, further restricting movement: 'the process of getting dressed in the 1880s', Cunningham comments, 'was a time-consuming ritual that resulted in a

\footnotetext{
${ }^{8}$ Edwina Ehrman, 'Women's Dress', in The Cult of Beauty: The Aesthetic Movement 1860-1900, eds. Stephen Calloway and Lynn Ferderle Orr (London: V\&A Publishing, 2011), 206-07 (p. 206).

${ }^{9}$ See Pauline Weston Thomas, 'The Aesthetic Dress Movement', Fashion Era.com < http://www.fashionera.com/aesthetics.htm> [accessed 21 May 2012].

${ }^{10}$ Quoted in Mary Eliza Haweis, The Art of Dress (London: Chatto \& Windus, 1879), p. 108.

${ }^{11}$ Haweis, Art, p. 110.

${ }^{12}$ Kortsch, Dress, p. 81.
} 
great deal of weight, constriction and bulkiness being added to the figure'. ${ }^{13}$ The critique of fashionable styles intensified in the latter part of the century, particularly through the mobilisation of the Rational Dress Movement. The Rational Dress Society, formed in 1881 as a result of a meeting between Viscountess Harberton and Mrs E. M. King, championed such items as loosened or 'hygienic' corsets, divided skirts or 'bifurcated' garments, and bicycling-costumes, in order to allow greater freedom of movement for women. The Rational Dress Association, the Rational Dress League and the Healthy and Artistic Dress Union (formed in 1890) followed suit. As suggested by their titles, these societies were concerned with matters of health and aesthetics: the Rational Dress Association's 'Requirements for a Perfect Dress' cited both 'Freedom of movement' and 'Grace and beauty combined with comfort and convenience' as part of their main criteria. ${ }^{14}$ In this sense, the Rational Dress Movement coalesced with the concerns of Artistic dress, as both movements aimed to 'reform women's dress to reflect philosophical, artistic, and medical agendas'. ${ }^{15}$ They did so particularly by rejecting the corset, the crinoline and the bustle, arguing that these supposedly fashionable styles restricted women's physical movements and created an ugly and unnatural silhouette. Aesthetic dress reformers, such as Haweis, therefore endorsed the classical figure as an alternative ideal:

What is gained by an ugly angular waist like a V? Nothing but a long list of hideous maladies which sap the health and spoil the complexion. What is gained by a somewhat larger 'antique' waist? Good proportion in an artist's eye, ease and grace of movement, of a really statuesque carriage, impossible to the slaves of la mode, with their hard, bony cuirasses on. ${ }^{16}$

\footnotetext{
${ }^{13}$ Cunningham, Reforming, p. 20.

${ }^{14}$ Quoted in Cunningham, Reforming, p. 69.

${ }^{15}$ Kortsch, Dress, p. 77.

${ }^{16}$ Haweis, Art, pp. 101-102.
} 
Bradley and Cooper were clearly influenced by such sartorial debates in the early part of their career. As Donoghue notes, during the 1870s the co-authors favoured the artistic dress promoted by the Pre-Raphaelites, rejecting 'corsets and crinolines in favour of daringly clinging dresses in arty colours such as peach, gold or green, with hair loosely knotted at the nape of the neck'. ${ }^{17}$ Mary Sturgeon also recounts how an undergraduate friend Herbert Warren 'poked bracing fun' at the poets' artistic dress: 'when someone mischievously asked him in Katharine's presence, "Who are this aesthetic crowd?" he promptly replied, "They're people as green as their dresses". ${ }^{18}$ Green was a colour particularly associated with Artistic dress, due to the PreRaphaelites' preference for dull, secondary tones. Haweis, for instance, recommended: 'oldfashioned blue which had a dash of yellow in it [...] even though it should look sadly faded [compared] to fashionable blues'. ${ }^{19}$

Following Gilbert and Sullivan's Patience (1881), a satirical portrait of the aesthetic movement: “Greenery-Yallery” colours quickly provided an easily recognisable shorthand for the general ridicule that greeted the perceived obsession of the Aesthetes with murky dull colours of all hues'. $^{20}$

Bradley and Cooper's journals, begun in 1888, are packed full of references to their wardrobe. Nearly every entry contains at least a brief description of what the women were wearing that day. These descriptions are often detailed, emphasising the colour combinations, sumptuous fabrics and dramatic accessories (particularly plumed hats and intricate jewellery) that

\footnotetext{
${ }^{17}$ Donoghue, Michael Field, p. 33.

${ }^{18}$ Mary Sturgeon, Michael Field (London: George G. Harrap \& Co, 1922), p. 22.

${ }^{19}$ Newton, Health, p. 73-4.

${ }^{20}$ Sally-Anne Huxtable, 'Re-reading the Green Dining Room', in Rethinking the Interior, c. 1867-1896, Aestheticism and Arts and Crafts, eds. Jason Edwards and Imogen Hart (Farnham, Surrey and Burlington, Vermont: Ashgate, 2010), 25-40 (p. 37).
} 
Bradley and Cooper carefully selected to suit each occasion. For example, at the premiere of their play A Question of Memory (1893), Cooper writes:

My Love wore her black + coral dress + a lovely green velveteen opera-cloak with silver clasp and black fur edgings. Two white flowers were bunched under the collar. I wore a dress of shimmery beryl green - white lace + black satin sash + breast-bow, deep red leaves + a Venetian red opera cloak, with black fur edge. ${ }^{21}$

We can interpret such details in light of aesthetic dress. For example, Bradley and Cooper's decision to combine harmonious 'secondary tones' of 'coral', 'beryl green' and 'Venetian red' chimes with aesthetic philosophies of colour: 'Colour juxtapositions and combinations of the kind variously used by Burne-Jones and Whistler', Newton states, 'had certainly been accepted and imitated in the early 'eighties by women who wore artistic dress'. ${ }^{22}$ Although it is difficult to find precise evidence of whether Bradley and Cooper subscribed to fashion magazines, the vocabulary used here (particularly to describe various hues of colour) clearly echoes that found in magazines such as the Woman's World (1886-1890), edited by Oscar Wilde (1887-1889). For example, an 1888 article on 'April Fashions' by Mrs. Johnstone describes hues of ‘eau de Nil, beryl, and young-leaf green, passing on through dim, mossy green, and delicate willow-green shot with white', while in 'May Fashions' she writes of a gown 'of shot silk that ran through every

\footnotetext{
${ }^{21}$ Edith Cooper's hand (hereafter EC), 28 October 1893, 'Works and Days’, London, British Library, Add. MS. 46781: vol. 6. All quotations from Bradley and Cooper's ‘Works and Day' are reproduced here by kind permission of the British Library and by the executors of Michael Field's literary estate, Charmain O’Neill and Leonie Sturge Moore.

22 Newton, Health, p. 84.
} 
tone of rose from that of the dying rose to flame, mingled with miniature stripes of ivorywhite'. ${ }^{23}$

Bradley and Cooper's diary descriptions served a number of different purposes. As Elizabeth Primamore notes, clothing marked significant emotional events in the poets' lives: 'Strong emotions, such as sadness and jealousy, were also expressed through costume'. ${ }^{24}$ Whether stepping out for the first (and last) public performance of their play, or mourning the death of their beloved dog Whym Chow in 1906, Bradley and Cooper faced life's vicissitudes, quite literally, with style. Clothing performed the role of public costume, displaying their artistic identity for all to see and occupying their most intimate moments, as the women fantasized about, designed, ordered and beheld each other in new gowns or jewellery pieces. For example, Cooper's narrow escape from scarlet fever in 1891 is poignantly marked by the acquisition of a 'fresh cotton jacket', purchased by their close friends Bernard Berenson and Mary Costelloe: 'The little white cotton jacket with black \& red spots was chosen by Bernie, bought by Mrs. C \& brought on Thursday, ${ }^{25}$

Bradley and Cooper were not only hyper-aware of their own dress. On meeting other people, a routine (usually rather unflattering) physical description of the individual's physiognomy, body-shape, size and bearing occurs — and dress is one of the most important details that Bradley and Cooper take pains to note. Such intricate details of clothing create distinctive portraits, revealing Bradley and Cooper's idiosyncratic reactions to these famous figures. For example, after they met fellow poet Lionel Johnson in 1891, Cooper remarks: 'We

\footnotetext{
${ }^{23}$ Mrs Johnstone, 'April Fashions’, Woman's World, 1 (1888), 281-88 (p. 288); 'May Fashions’, Woman's World, 1 (1888), 329-36 (p. 335).

${ }^{24}$ Elizabeth Primamore, 'Michael Field as Dandy Poet', in Michael Field and their World, eds. Margaret D. Stetz and Cheryl A. Wilson (High Wycombe: Rivendale Press, 2007), 137-46 (p. 141).

${ }^{25}$ EC, 30 August 1891, 'Works’, Add. MS. 46779: vol. 4.
} 
looked down at Lionel's feet - they were fabulous, tiny, in girlish shoes, and blue silk stockings' ${ }^{26}$ They were equally struck by the Wildes' outlandish fashions:

We visit Oscar Wilde - being received by Mrs Oscar in turquoise blue, white frills + amber stockings. The afternoon goes on in a dull fashion until Oscar enters. He wears a lilac shirt, a heliotrope tie, a great primrose pink - very Celtic combination, ma foil ${ }^{27}$

The Wildes were deeply associated with both the Aesthetic and Rational dress reform movements of the late nineteenth century. Constance Wilde was herself an active member of the Rational Dress Society, formed in 1881, which aimed to 'promote the adoption, according to individual taste and convenience, of a style of dress based upon considerations of health, comfort, and beauty, and to deprecate constant changes in fashion that cannot be recommended on any of these grounds'. ${ }^{28}$ As Cooper's diary entry attests, Constance wore the 'stockings' or knickerbockers recommended by the Society as an alternative to restrictive, heavy petticoats, which could be worn either beneath a dress, or, more radically, as an outer garment. Constance particularly favoured Turkish trousers, which she promoted in her article 'Children's Dress in this Century' (published in the Woman's World, July 1888) and wore herself: 'She attended a meeting in Westminster Town Hall in March 1886, and [...] showed herself to be clad in cinnamon-coloured cashmere trousers'. ${ }^{29}$

Wilde, given his penchant during the early 1880s for medieval styles of dress, kneebreeches, fur coats, velvet jackets, long hair (and for reportedly carrying sunflowers and lilies)

\footnotetext{
${ }^{26}$ EC, 23 April 1891, 'Works ', Add. MS. 46779: vol. 4.

${ }^{27}$ EC, 17 June 1891, 'Works', Add. MS. 46779: vol. 4. The French expression 'ma foi' translates as 'my faith', but is used as an equivalent to 'indeed!'.

28 'Divided Skirts’, Rational Dress Society Gazette, April 1888, no page numbers.

${ }^{29}$ Richard Ellmann, Oscar Wilde (Harmondsworth: Penguin, 1988), p. 259.
} 
had been satirized in Gilbert and Sullivan's Patience (1881) as Bunthorne, a 'greenery-yallery, Grosvenor Gallery / Foot-in-the-grave young man'. ${ }^{30}$ A year before the operetta opened, Bradley and Cooper were likewise ambivalent about the increasing popularity of aesthetic dress as an extension of aestheticism in art. For example, in 1880, Cooper wrote to Bradley that:

all the corruption that covers itself in sage greens, and thoughtful blues, and passionate golds, cannot deprive me of the firm conviction that, since Wordsworth sings,

'The eye it cannot choose but see'

beautiful objects, noble in their forms, and pure in their colour, ought to be given it for food. [...] I believe that the unhealthiness that is rank in the modern revival of Art is due to the lovelessness of its votaries. They no more love it than the latest fashion in dress. ${ }^{31}$

The poets' snide reaction to the Wildes' unconventional outfits therefore suggests their own rather more cautious attitude towards dress reform. They were perhaps fearful that their own interest in dress could potentially overwhelm what they saw as their more 'serious' aesthetic vocation; that of writing poetry.

Nonetheless, Bradley and Cooper took great pains to note down their own dress, particularly on special occasions. For example, in May 1892, they dressed up to meet the writer George Meredith, whom they greatly admired: 'Sim wears her Velasajuez [sic] dress + black plumed hat - I my new dress of black cloth faced with olive silk $>$ that is $<$ darkened with by black lace, black hat with olive bow, a lilac spray, + lilac baby ribbons' ${ }^{32}$ The juxtaposition of olive-green tones with lilac and black lace recalls Whistlerian colour harmonies - a combination

\footnotetext{
30 The Complete Annotated Gilbert and Sullivan, ed. Ian Bradley (Oxford: Oxford University Press), p. 347.

${ }^{31}$ EC to KB, 'Friday' September 1880, reprinted in The Fowl and the Pussycat: Love Letters of Michael Field, 1876-1909, ed. Sharon Bickle (Charlottesville: University of Virginia Press, 2008), pp. 34-5.

32 EC, 2 May 1892, 'Works', Add. MS. 46780: vol. 5.
} 
somewhat similar to that worn by George Meredith's fictional heroine, Diana of the Crossways (1885). ${ }^{33}$ This passage alone suggests how Bradley and Cooper relied on clothing to create dramatic effect; plumed hats and lilac sprays advertise their identity as poets, while these clearly contrasted ensembles play up to their uniqueness as two separate women, emphasising and enhancing their different colouring, ages, physiques and tastes, for the women were markedly different in appearance. This difference is epitomized in a physical description given by their friend, the artist Charles Ricketts: 'Michael [Bradley] was small, ruddy, gay, buoyant and quick in word and temper, Henry [Cooper] was tall, pallid, singularly beautiful in a way not appreciated by common people'. ${ }^{34}$

This assertion of selfhood through dress recalls Michael Field's own poem 'A Portrait' (from Sight and Song, 1892), in which the female subject 'questions long / Which flowers to choose of those the summer bears' and finally 'to the prompting of her strange, emphatic insight true, / [...] bares one breast, half-freeing it of robe, / And hangs green-water gem and cord beside the naked globe'. ${ }^{35}$ Here, Michael Field imbue the artist's model with her own agency: she determines '[s] he will be painted' and becomes master of her own representation, an artist in her own right, through choosing the flowers and gems with which she will adorn herself. In a similar way, Bradley and Cooper asserted their own artistic identity by self-consciously transforming themselves into works of art; just as they carefully selected the olive-green cover of Sight and Song, they clothe themselves in 'olive silk' in order to create an impression that acquaintances, such as George Meredith, were unlikely to forget.

Bradley and Cooper's exquisite gowns were painstakingly planned and discussed with dressmakers. As William Rothenstein recalls in his introduction to the 1933 volume that printed selections from Works and Days: 'dress, like everything else, must for long be discussed and

\footnotetext{
33 See Newton, Health, p. 79.

${ }^{34}$ Quoted in Sturgeon, Michael Field, p. 38.

${ }^{35}$ Michael Field, 'A Portrait', Sight and Song (London: Elkin Mathews and John Lane, 1892), p. 28.
} 
pondered and finally ordered from the modiste with elaborate directions. ${ }^{36}$ According to evidence from their diary, Louis Ellis, the sister of the sexologist Havelock Ellis, made many of their dresses. Bradley and Cooper befriended her in 1887. The Ellis siblings moved to 9 St Mary's Terrace, Paddington, in September 1888, where Louie set up a business as a dressmaker, aiming her services specifically at ladies who were to be presented at court. ${ }^{37}$ As Ellis' most beloved sister, Louie was fully integrated into his intellectual and personal life, including his intimate friendship with Olive Schreiner: 'Louie became an integral part of their relationship. Louie, trading on her experience as a dress-maker, advised Olive, in precise detail, about what she should wear'. ${ }^{38}$ Ana Parejo Vadillo notes that Louie had 'made her apprenticeship with Mrs Nettleship [...] the dressmaker of the actress Ellen Terry'. ${ }^{39}$

Louie Ellis clearly had more than a business relationship with Bradley and Cooper. For example, in March 1892, Cooper notes that the women attended: 'A dress-conclave at Louie Ellis". ${ }^{40}$ A few days later, Cooper records: 'A dress-congress with Louie: I describe a Watts hat black, olive green + faint heliotrope - she is to see + copy'$^{41}$ Such intimate meetings were social

\footnotetext{
${ }^{36}$ William Rothenstein, 'Introduction', Works and Days: From the Journal of Michael Field, ed. T and D. C. Sturge-Moore (London: John Murray, 1933), p. xii.

${ }^{37}$ Phyllis Grosskurth, Havelock Ellis: A Biography (London: Allen Lane, 1980), p. 122.

${ }^{38}$ Chris Nottingham, The Pursuit of Serenity: Havelock Ellis and the New Politics (Amsterdam: Amsterdam University Press, 1999), p. 41.

${ }^{39}$ Vadillo, 'Living Art', no page numbers (proof copy).

${ }^{40}$ EC, 30 March 1892, 'Works', Add. MS. 46780: vol. 5.

${ }^{41}$ EC, 2 April 1892, 'Works', Add. MS. 46780: vol. 5. G. F. Watts had contributed to fashion debates with his article On Taste in Dress (1884). In this article, Watts declared "that bonnets made of "dense" materials should be small and that when large hats were worn these should be made of light and airy materials' (quoted in Newton, Health, p. 81). The specific hat to which Cooper refers here may appear in one of Watts's paintings, though I have been unable to track it down.
} 
as well as practical occasions, in which the women tried on new gowns, discussed alterations, and beheld the dressmaker herself in fine array:

My robe of black \& bright olive-green veiled with black lace is severe \& rather dark. Louie herself was worthy of Sargeant's [sic] brush - a fine green tea-gown, boldly embroidered with damask-velvet thread \& the high lights flushed across it with brilliant blood-red beads, ${ }^{42}$

Louie Ellis's dress here is clearly aesthetic; embroidery and 'art beads' were key ingredients of the aesthetic 'look', whilst the 'tea gown' or 'house gown' was associated with artistic types in the 1860s, who dared to wear such light and loose-fitting attire out in public. ${ }^{43}$ By the 1890 s, the teagown had become a highly fashionable item, commonly worn at 'aesthetic functions - the opening of the Grosvenor Gallery, "at homes", and balls..

Bradley and Cooper's gatherings with Louie Ellis, resembling domestic fashion-shows, anticipate Lucile Duff-Gordon's intimate shop-floor parades, which took place during the early 1900s. ${ }^{45}$ Such 'mannequin parades', as Joel H. Kaplan and Sheila Stowell have remarked, were 'forerunners of the contemporary fashion show', replicating 'on a show room floor the particulars and ambience of society gatherings' as mannequins 'perambulated about the costume rooms, mingling with spectators and one another'. ${ }^{46}$ These 'dress-conclaves' between Bradley, Cooper and Louie Ellis also recall the literary salons, socialist and suffrage meetings that took

\footnotetext{
42 EC, 30 March 1892, 'Works', Add. MS. 46780: vol. 5.

${ }^{43}$ Cunningham, Reforming, p. 114.

${ }^{44}$ Cunningham, Reforming, p. 114.

${ }^{45}$ For more information see Lucile Ltd.: London, Paris, New York and Chicago, 1890s-1930s, eds. Valerie D. Mendes and Amy De La Haye (London: V\&A Publishing, 2009).

${ }^{46} \mathrm{Joel} \mathrm{H.} \mathrm{Kaplan} \mathrm{and} \mathrm{Sheila} \mathrm{Stowell,} \mathrm{Theatre} \mathrm{and} \mathrm{Fashion:} \mathrm{Oscar} \mathrm{Wilde} \mathrm{to} \mathrm{the} \mathrm{Suffragettes} \mathrm{(Cambridge:} \mathrm{Cambridge}$ University Press, 1994), pp. 117-19.
} 
place at the turn of the century — in the sense that these gatherings provide a space for women to come together, forging personal relationships and engaging in various forms of collaboration. For example, the Rational Dress Society held women-only meetings, presented at several exhibitions (including the International Health Exhibition of 1884) and published a short-lived Gazette in 1888. Constance Wilde was heavily involved with these activities; she edited the Gazette from its inception in April 1888 until its final issue in July 1889 and presided over a meeting of the Society in February 1887:

It was an event to which, the press noted, only women were admitted, and at which Constance gave an introductory speech. After Viscountess Harberton had spoken, a number of women who were sitting on the platform, including Constance, modelled the divided skirt for interested onlookers. ${ }^{47}$

In contrast to such events, Bradley and Cooper's dress 'congresses' with Louie Ellis appear to have been rather private affairs; there is no evidence to suggest that anyone else was present, besides the three women. Unlike other aesthetic women of their day, Bradley and Cooper did not officially belong to any dress reform groups, nor did they contribute to dress reform journals or magazines. Their absence from such groups may be due to the fact that they tended to view themselves as a somewhat isolated dyad. The co-authors identified as artists first and foremost, viewing their female identity as of secondary importance. Cooper makes this clear in this diary entry: 'I should never fight for any freedom that to gain wh. would perturb my art. I have only so much energy — if the god demands it — the cause of womanhood must go hang! ${ }^{48}$

Bradley and Cooper's dress was quite literally 'artistic' — as the above examples from their diary show, with their references to Diego Velázquez, John Singer Sargent and George

\footnotetext{
${ }^{47}$ Franny Moyle, Constance: The Tragic and Scandalous Life of Mrs Oscar Wilde (London: John Murray, 2011), p. 142.

${ }^{48}$ EC, n.d. 1895, 'Works', BL Add. MS 46780: vol. 5.
} 
Frederick Watts. William Gaunt wryly observes that for late-Victorian women '[a]rt was important enough now to be confused with fashion. What kind of art was a matter of choice. Some women became like Pre-Raphaelite pictures' ${ }^{49}$ Bradley and Cooper were no exception. For example, in early 1890 the women were intrigued to encounter a Pre-Raphaelite model, Margaret Drummond, first-hand. Cooper's entry took pains to note the particulars of Mrs Drummond's dress: the colour-combinations, materials and textures that make up the famous Pre-Raphaelite 'look':

At this point called entered - Mrs M. Drummond, Burne-Jones' celebrated sitter + model with her mother. The daughter sat like an "Angel of Creation" — every wonder of the type was there [...] She wore a cloak of dark peacock green + fawn boa, round her bonnet, like the cloak in shade, little peacock feathers of the softest hue + shimmer mingled with the hair. ${ }^{50}$

The women found similar fashion inspiration in Pre-Raphaelite paintings. On viewing Dante Gabriel Rossetti's portrait The Beloved (1865-66) during a loan exhibition at the Guild Hall, Cooper observed precise details of 'colour-grouping' and jewellery:

Rossetti's Beloved is most lovely in colour-grouping. The chief half-length figure is in sunny yellow green with pine-green scarf - on her gown is vermillion + pine-green broidery. Within her golden hair are little vermillion fanlike ornaments. ${ }^{51}$

\footnotetext{
${ }^{49}$ William Gaunt, The Aesthetic Adventure (originally published 1945; London: Cardinal, 1975), p. 62.

${ }^{50}$ EC, 2 January 1890, 'Works’, Add. MS. 46778: vol. 3.

${ }^{51}$ EC, 8 August 1890, 'Works', Add. MS. 46778: vol. 3.
} 
Bradley and Cooper clearly shopped in the right places to attain the aesthetic look, too. Several entries from their diary during 1890-1891 make reference to shopping in Morris and Co. and Liberty's: stores that were deeply associated with the Aesthetic dress movement. Arthur Lasenby Liberty's shop (founded in 1875) specialized in ornaments, fabrics, and art from the 'East', including silks imported from India and 'art fabrics', which used Persian dying techniques. ${ }^{52}$ In 1884 , the store expanded to include a costume department headed by the architect and designer Edward Godwin. This department offered 'historically inspired styles made in their fabrics' and also included pyjamas imported from India. ${ }^{53}$ Morris's shop also specialized in handmade textiles, in keeping with the philosophy of the Arts and Crafts Movement. Such fabrics could be used for home decoration, such as furniture upholstery, or as dress fabrics.

Bradley and Cooper record frequent visits to both shops. During Easter of 1891, the women visit Morris \& Co. while hunting for new decor: 'At Morris’ we order our Brussels carpet to be wove - yellows mix on clouded cream and are bordered with blue in tone with lavendered, seen through green stems with a fleck of rare pink for a bloom'. ${ }^{44}$ They shopped at Liberty's for Christmas presents in the same year, and their maids reciprocated with hand-made gifts in aesthetic fabric: 'To Father from us all a flower-sprinkled quilt - very pretty - from Liberty's [...] The maids gave to Sim + me lovely n. dress cases + comb-bags worked by themselves in art colours'. ${ }^{55}$

Interior decoration was as important to Michael Field as clothing. In 1899, they moved to their first independent home: 1, The Paragon, Richmond. They furnished each room in their

\footnotetext{
52 Sonia Ashmore, 'Aesthetic Textiles' in The Cult of Beauty: The Aesthetic Movement 1860-1900, eds. Stephen Calloway and Lynn Ferderle Orr (London: V\&A Publishing, 2011), 140-143 (p. 142).

${ }^{53}$ Ehrman, ‘Women's Dress’, p. 206.

${ }^{54}$ EC, 'Monday of Passion Week’ March 1891, ‘Works’, Add. MS. 46779: vol. 4.

${ }^{55}$ EC, 25 December 1891, 'Works', Add. MS. 46779: vol. 4. ['Sim’ was one of Katharine Bradley’s many nicknames]
} 
new home with the utmost care, selecting individual objects that combined to create an overall artistic impression. The following account from Gordon Bottomley demonstrates the attention Bradley and Cooper paid to ensuring that the new home reflected their artistic passions:

Their rooms were not less flawless than their poems. Their interiors showed a rare, wider more certain choice than those of the Dutch painters. The silvery clear lithograpths of their friend, Mr C. H. Shannon, were hung all together in a cool northern room [...] in another room the golden grain of the walls, alike with the Persian plates that glowed on the table as if they were rich, large petals, seemed to find their reason for being there in the two deeply and subtly coloured pictures by Mr Charles Ricketts on the walls. But always there was the same feeling of inevitable choice and unity everywhere; in a jewelled pendant that lay on a satinwood table, in the opal bowl of pot-pourri nearby on which an opal shell lay lightly. ${ }^{56}$

Bradley and Cooper sometimes became utterly consumed by interior decoration. In 1891, during the Easter Holy Week, Cooper lamented that she was '[d]istracted by patterns of stuffs - tragicomedy of mortal life that such a thing should distract from absorption in the divine death! ${ }^{57}$ In this respect, we can read Bradley and Cooper's home in relation to the theories of 'queer intimacy' that John Potvin has discussed. Potvin argues that Bradley and Cooper's close friends, the artists Charles Ricketts and Charles Shannon, reconfigured the domestic interior as a 'queer space' by accumulating and displaying aesthetic objects that attested to both their identity as artists and their love for one another: 'art collecting and community became the hallmarks of

\footnotetext{
${ }^{56}$ Quoted in Sturgeon, Michael Field, p. 52.

${ }^{57}$ EC, 'Good Friday’ 27 March 1891, 'Works', Add. MS. 46779: vol. 4.
} 
Ricketts and Shannon's shared vision of aesthetic domesticity'. ${ }^{58}$ The same can be said for Bradley and Cooper, whose home, like their fashion choices, reflected both their claim to aesthetic identity and their life-long homoerotic bond.

\section{Dressing to Impress: Michael Field and the Male Aesthetes}

Admiring and buying hats and dresses and decorating their home also functioned as way in which Michael Field participated in the increasingly professionalized, male-dominated world of art criticism. In 1890, Bradley and Cooper met Bernard Berenson, a young and up-and-coming art critic who specialized in Renaissance art. The women eventually employed Berenson as their private tutor, accompanying him on a gallery tour of Paris in 1892: a visit that formed the foundation of their collection of ekphrastic poems, Sight and Song. This friendship with Berenson and his partner Mary Costelloe meant that Bradley and Cooper became versed in Morellian art criticism: an approach which placed particular emphasis on colour, light, shade, and texture, in order to identify the work of different artists.

Due to these new interests, Bradley and Cooper increasingly based their dresses on the paintings they saw in European art galleries. In this respect, they followed Mary Eliza Haweis, who urged readers that ' $[\mathrm{m}]$ any very rich and complicated sleeves may be adopted from old pictures by Rubens, Rembrandt, and others. In these days of loan collections we have every advantage for studying ancient fashions, ${ }^{59}$ Bradley and Cooper attempted to follow this example on a trip to Dresden in 1891. Looking at a painting that Berenson attributes to Lorenzo Lotto, Cooper notes:

\footnotetext{
${ }^{58}$ John Potvin 'The Aesthetics of Community: Queer Interiors and the Desire for Intimacy', in Rethinking the Interior, c. 1867-1896, Aestheticism and Arts and Crafts, eds. Jason Edwards and Imogen Hart (Farnham, Surrey and Burlington, Vermont: Ashgate, 2010), 169-184 (p. 172).

${ }^{59}$ Haweis, Art, pp. 103-04.
} 
A glorious red curtain hangs three parts across a window; the Madonna sits in its deep shade - her dress is pallid heliotrope, with a rim about the neck + sleeves of old gold that harmonises the robe with the severe blue cloak. ${ }^{60}$

Following this entry there is a sketch carefully labelled with the relevant colours, and then there is a note that reads: 'Hint for a dress'.

Just as they looked to Renaissance paintings for sartorial inspiration, Bradley and Cooper in turn viewed their dresses as art-objects: ones that were to be carefully planned, constructed and displayed to the public gaze. During a trip to an art gallery after her recovery from scarlet fever in 1891, Cooper dresses for dramatic impact, choosing a black lace gown to enhance her lingering pallor. In doing so, she manages to draw as much attention as the paintings themselves: 'I am watched suspiciously by the people as I lie back under the Sistine Madonna in the black folds of my lace, haggard + half-fainting. ${ }^{61}$ Similarly, during a visit to Italy Bradley insisted on wearing 'a heavy fur about her neck on the hottest days "to keep me cool". ${ }^{62}$ In order to account for Bradley and Cooper's oddities, Mary Costelloe explains that she 'told the people they were Poets like Dante and Ariosto and Tasso, and they were immensely impressed'. ${ }^{63}$ This somewhat comic example reveals the extent to which the co-authors performed their poetic identity — and that such an identity in part exempted them from the mundane rules of dress to which nonartistic women were subject.

\footnotetext{
${ }^{60}$ EC, 11 August 1891, 'Works', Add. MS. 46779: vol. 4.

${ }^{61}$ EC, 'Tuesday' ca. late-August-September 1891, 'Works', Add. MS. 46779: vol. 4.

${ }^{62}$ Mary Berenson (Costelloe), Letter to Hannah Whitall Smith, 25 May 1893, reprinted in Mary Berenson: A Self-

Portrait from her Letters \& Diaries, eds. Barbara Strachey and Jayne Samuels (London: Norton, 1983), p. 53.

${ }^{63}$ Berenson, Letters \& Diaries, p. 53.
} 
However, Bradley and Cooper's penchant for fashion-as-art also exposed them to uncomfortable aesthetic scrutiny from their male peers Oscar Wilde and Bernard Berenson, who saw the women's clothing as works of art to be analyzed and mercilessly criticized. In other words, through their dress in particular, Bradley and Cooper came to occupy the role of aesthetic objects as well as subjects, exposing themselves to rigorous aesthetic appraisal. Such scrutiny is found in a record of an encounter with Oscar Wilde, which — aptly — took place in the National Gallery:

As we are looking at this [Lorenzo] Costa Oscar comes up; he shakes hands with Mrs C. + therefore I put out my hand wh. he takes (afar off) + never addresses a single word to me after. Sim bows, he returns the bow (afar off) + never addresses a single word to her after. I have not often seen such rudeness. [...] When he shows himself a snob he is disgustingly repulsive. We were not well-dressed as the day had begun with rain - we do not belong to the fashionable world - so Oscar rolls his shoulders toward us. When next I meet him in my choicest French hat I will turn my back on him decisively. The artiststrain in him is crossed by the Vulgar-respectable - Gods + women cannot endure such a cross. $^{64}$

Wilde's snobbish reaction to the women's démodé dress recalls Olive Schreiner's critique of the male aesthete as a callous, shallow creature:

The most degraded type of human creature I have ever known is also one of the most aesthetic. A man that will send a little child quivering and crying out of a room because she has on a dress whose colour does not please him, [...] such a man is so immersed in

\footnotetext{
${ }^{64}$ EC, 25 May 1892, 'Works', Add. MS. 46780: vol. 5.
} 
the lower forms of aesthetic feeling that one knows the higher must be forever shut off from him. ${ }^{65}$

However, Schreiner's caricature of the misogynist male aesthete does not fully account for Bradley and Cooper's sartorial insecurities in Wilde's presence. For example, the dynamic between the male and female aesthete did not always play out this way — many women who participated in dress reform movements felt male aesthetes were allies to their cause. Wilde, for instance, encouraged Constance to experiment with fashion, and the Woman's World — which he edited — contained a number of articles in support of the Rational Dress Movement. ${ }^{66}$ Furthermore, participation in such groups as the Rational Dress Society and the Healthy and Artistic Dress Union meant many women began to experience fashion as a source of pleasure and authority, linking them to groups of like-minded women, without any need for external male approval.

Bradley and Cooper's somewhat defensive reaction therefore suggests they felt to some extent outside the worlds of fashion and aesthetic dress. These insecurities may perhaps stem from the fact that Bradley and Cooper did not participate fully in any of the dress reform movements of the period. Such an involvement might have bolstered their confidence to dress as they liked, regardless of male approval. In a wider sense, throughout their career Bradley and Cooper's often experienced ambivalent feelings towards the groups with which they were partially aligned. For example, they rejected the decadent movement and the literary periodical The Yellow Book (1894-1897), which was heavily associated with the movement, declaring: 'From decadence, Good Lord deliver us! ${ }^{67}$ They were suspicious of fashionably dressed women and

\footnotetext{
65 Olive Schreiner, Letter to Karl Pearson, 6 July 1886, reprinted in Olive Schreiner Letters, ed. Richard Rive (London: Oxford University Press, 1985), Vol I, p. 88.

${ }^{66}$ Newton, Health, p. 119. Wilde also wrote several pieces on dress reform for the Pall Mall Gazette.

${ }^{67}$ Katharine Bradley (KB), n.d. 1891 ,'Works', Add. MS. 46779: vol. 4
} 
unfashionably dressed women alike, remarking after a party at Ricketts and Shannon's: 'With the exception of us, all the women with brains were ill-drest \& dowdy; the well dressed women were idiots'. ${ }^{68}$ Evidently, Bradley and Cooper preferred to see themselves as neither part of nor outside the fashionable world.

The occasional failure to impress, however, did not deter Bradley and Cooper from using fashion as a major tactic for constructing and advertising their aesthetic identity. Notice that Cooper accepts the terms of Wilde's judgment and intends to fight them in kind, resolving to snub him in her 'choicest French hat'. Rather than rejecting the 'lower forms of aesthetic feeling', Bradley and Cooper embrace trivial matters such as sartorial taste, using their dress both to announce their artistic identity and as a weapon to defy their critics.

Bernard Berenson was particularly inclined to judge Bradley and Cooper's clothes using his methods of art criticism. Not surprisingly, this eventually led to tension when Bradley and Cooper went to stay with Berenson and Costelloe in the summer of 1892. As the Parisian visit progressed, Cooper observed: 'He never walks with either of us [...] He does not like our dress can it be he is small enough to retreat merely from folds \& colours that dees try him? ${ }^{69}$ The next day, Berenson made his feelings clear by embarking on a devastating critique of the women's hats:

the little villain begins 'Miss Cooper, you will forgive me - I like everything about you, but your hat - those flowers in front are too dreadful, they try my nerves every time I look at them'. He then takes the occasion for bullying our hats, the 'vegetables' we wore wear in them (all French flowers specially arranged by Mme Vérén for Parisian taste!) $[\ldots]$ He wheedles me into the promise I would will take out the offending bunch. ${ }^{70}$

\footnotetext{
${ }^{68}$ KB, 12 December 1903, 'Works', Add. MS. 46792: vol. 17.

${ }^{69}$ EC, 24 June 1892, 'Works', Add. MS. 46780: vol. 5.

${ }^{70}$ EC, 25 June 1892, 'Works', Add. MS. 46780: vol. 5.
} 
As the above passage shows, despite Bradley and Cooper's efforts to live up to the cutting-edge of 'Parisian taste' Berenson's aesthetic opinion dominates — to the degree that the flowers are removed and eventually demoted to dining-table decorations (which fails to please Berenson). As late as 1893 , the women are still struggling to satisfy their exacting mentor — removing beloved items of furniture in an effort to become 'contemporaneous': 'Every Millet, every Turner has been banned from study \& blue-room. Italian art alone remains. This new god's single command

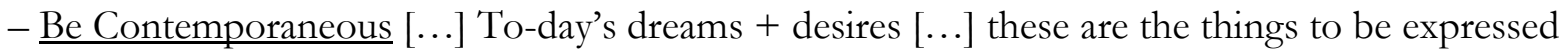
on our walls, in our furniture in our dress'. ${ }^{71}$

Judging from the diary accounts, it is clear that Berenson used both his aesthetic expertise and his masculine privilege to undermine Bradley and Cooper through criticizing their dress. On a sweltering hot day in July 1892, Berenson insisted that Bradley must not wear a blouse to the opera. Cooper transcribed the quarrel that ensues: "'O Mary can wear anything but Miss Bradley you cannot" "Why should not Miss Bradley dress as she likes" - "Oh, I am a man" - is the insulting rejoinder. ${ }^{72}$ Martha Vicinus has argued that the tensions of this Parisian visit arose from Cooper's romantic feelings for Berenson. Vicinus contends that Cooper's love for Berenson profoundly threatened the Field partnership: 'Berenson pried apart [Bradley and Cooper's] private persona as a devoted couple and forced each woman to reconsider what "Michael Field" meant'. ${ }^{73}$ Donoghue agrees that 'all Katherine seems to have wanted from BB was an intense intellectual friendship. Edith's feelings for him were more erotic' ${ }^{74}$ But laying aside speculation about the personal feelings underlying these events, it is clear that during the

\footnotetext{
${ }^{71}$ KB, 12 July 1893, 'Works’, Add. MS. 46781: vol. 6.

${ }^{72}$ EC, 4 July 1892, 'Works', Add. MS. 46780: vol. 5.

${ }^{73}$ Martha Vicinus, 'Sister Souls: Michael Field and Bernard Berenson', Nineteenth-Century Literature, 60.3 (2005), 326354 (p. 328).

${ }^{74}$ Donoghue, Michael Field, p. 70.
} 
most intense period of their friendship, Berenson's propensity to judge Bradley and Cooper's dress caused increasing conflict: by treating the women as art objects, he rendered them frustrated and powerless. To a degree, Bradley and Cooper therefore became victims of their own self-fashioning; the distinctive hats, clothes and jewellery that they selected for their trip simultaneously defined them as artistic subjects and condemned them as aesthetic objects that Berenson judged.

Berenson's desire to construct Cooper as his 'follower' eventually contributed to the breakdown of his friendship with Bradley and Cooper. Berenson attempt to control Cooper's artistic productions by pressurising her to write croquis (short, descriptive prose sketches) rather than her favoured forms of lyric poetry and verse drama. During an 1894 stay in Italy, Berenson's intentions came aggressively to the fore: 'He allowed all his disappointment to escape that I have not given up my life \& followed him [...] He would like me to be his Maenad; he has no intention of serving me'. ${ }^{75}$ By late 1895 , the realization that Berenson had derived many of his ideas from Nietzsche — coupled with Mary Costelloe's patronizing letters regarding the shortcomings of their play Attila My Attila! (1895) — brought an end to Bradley and Cooper's relationship with this couple. Bradley eventually wrote a letter that severed this friendship on 29 November 1895 (though she and Cooper continued to see Berenson and Costelloe again later in their lives).

Following their intense attachment to Berenson, Bradley and Cooper subsequently sought aesthetic approval from Charles Ricketts and Charles Shannon. On meeting the two men in 1894, Bradley and Cooper quickly recognized a couple who enjoyed a romantic and artistic partnership that resembled their own: 'Ricketts] is an ardent lover of Shannon, his elder by a year, loving him as my Love loves me'. ${ }^{76}$ Ricketts eventually designed and published a number of beautiful book covers for Michael Field, as part of his Vale Press series, including the intricate

\footnotetext{
75 EC, 16 July 1894, 'Works', Add. MS. 46782: vol. 7.

${ }^{76}$ EC, 22 May 1894, 'Works', Add. MS. 46782: vol. 7.
} 
bindings and dramatic woodcut title pages for Michael Field's Roman trilogy: the verse dramas The World at Auction (1898), The Race of Leaves (1901) and Julia Domna (1903). In turn, the poets dressed up and decorated their home to impress the artists. Prior to one of their early meetings, Cooper hastily changed into a dramatic outfit more appropriate to the Ricketts and Shannon's tastes: 'I know there is nothing to please the artist-eye in my black dress - so I put on my red cloak + Tam'.77

In contrast to their rather one-sided relationship with Berenson, Bradley and Cooper's friendship with Ricketts and Shannon formed itself along more reciprocal and mutually creative lines: Ricketts clothed Michael Field's books, while they clothed themselves for him. ${ }^{78}$ The women also wrote poems inspired by their artist friends; for example, the poem 'Penetration'. ${ }^{79}$ Bradley and Cooper's mutually productive dynamic with Ricketts and Shannon ran along complex lines of gender and sexuality, identification and desire. This affinity between the couples is shown, for example, when Ricketts displays a feminine interest in Cooper's mourning gown, following Queen Victoria's death in 1901:

Miss Eaton brings over my pale white silk with hardest trimmings of black to try with it [...] the painter touches it lingeringly - by a subtle emphasis of sensation suggesting he would like to be of the sex that could wear it - as a woman handles the red coat of a solider. $^{80}$

\footnotetext{
77 EC, 22 May 1894, 'Works’, Add. MS. 46782: vol. 7. ‘Tam’ presumably means a 'tam o’shanter'; a woollen Scottish bonnet named after the eponymous hero of Robert Burns' 'Tam O' Shanter' (1790).

${ }^{78}$ Bradley and Cooper saw their book covers in terms of clothing: 'Suddenly our little book is disappointed of its clothes + we do not know how to cover its nakedness. Olive-cloth is suggested' (EC, 30 March 1892, 'Works', Add. MS. 46780: vol. 5).

${ }^{79}$ Michael Field, Wild Honey from V arious Thyme (London: T. Fisher Unwin, 1908), p. 13.

${ }^{80}$ EC, 15 February 1901, 'Works’, Add. MS. 46790: vol. 15.
} 
Cooper's diary entry then ventriloquizes Ricketts' voice, campily intoning:

But the silk is too dreamy for anyone but Worth to handle it - There should be motives $[$ sic] in black Brussels lace on it - here + there a butterfly or knot on the skirt [...] The Fairyman becomes feminine to the finger-tips to the tip of the tongue, in praising the Bond Street shops at this time of mourning - the black + white silks, the cobweb greys (We shall be clothed in the sweepings of our own corners!) - the chiffons that flow duskily. In another life, Ricketts was a woman. ${ }^{81}$

As this passage shows, Cooper and Ricketts's cross-gendered identifications were concentrated and covertly expressed through fashion. Ricketts' desire to wear the gown, communicated through his lingering touch, reminds Cooper of how 'a woman handles the red coat of soldier'. In this sense, Cooper relates to Ricketts's desire to wear the clothing of the opposite sex. Reflecting on his overt admiration and enjoyment of feminine fashions, she indirectly acknowledges a parallel desire within herself. In other words, the effeminacy that Cooper recognizes in Ricketts reflects her own enjoyment of gender subversion, which she expressed through occasionally adopting a boyish identity. Her boyishness certainly emerged in August 1891, when Cooper was struck down by scarlet fever while she and Bradley were on holiday in Dresden. As part of her treatment, her hair had to be cut very short. At first 'grave and depressed at the thought of being clipped', Cooper later revelled in her short haircut, which led an amorous German nurse to christen her 'Heinrich'. Cooper clearly enjoyed this new boyish identity, copying Bradley's admiring comments into her diary: 'She looks very pretty in her short boy's hair \& fresh cotton jacket'. ${ }^{82}$ For his part, Ricketts self-consciously played up to the role of

\footnotetext{
${ }^{81}$ EC, 15 February 1901, 'Works', Add. MS. 46790: vol. 15. 'Fairyman' was one of the poets' many nicknames for Ricketts.

82 EC (KB's words), 30 August 1891, 'Works', Add. MS. 46779: vol. 4.
} 
the camp fashion connoisseur, as we can see in his reference to Charles Worth, recognized by many as the founder of haute couture, and his mock-tragic exaggeration: 'we shall be clothed in the sweepings of our own corners!' Such words transform the occasion of mourning the sovereign's death into a delicious sartorial challenge.

The collaborative bond between the poets and artists was forged through their discussion of the latest fashions and their gift-giving. In addition to book-bindings, Ricketts also designed a number of stunning jewellery pieces for the women, now held in the Fitzwilliam Museum, Cambridge. These include the Pegasus pendant, containing a miniature portrait of Cooper, and the Sabbatai ring, which was shaped like a mosque. This ring was given to Bradley on 5 February 1904. When Bradley wore the ring on a chain around her neck, this provoked a conversation about the best way to display one's cleavage: 'Fay is charmed by the ring Solomon in Michael's "entre sein" - We talk toilette - how the breasts run wild in the new Samothrace corsets - They should be lifted somewhat like wine bottles raised for pouring! ${ }^{83}$ This brief exchange, though apparently trivial, reveals much Bradley and Cooper's relationship with Ricketts and Shannon, as well as the context within which this discussion takes place. First, this exchange gives an idea of the relaxed intimacy between the couples. The group shared opinions on how the female body should display itself: a discussion combining aesthetic and erotic interest. Secondly, the mention of the 'Samothrace' contextualizes their debate in relation to the history of the corset. 'La Samothrace' was a new brand of corset sold by the London Corset Co. This new 'S' bend corset was designed to flatten the stomach and push out the breasts, in contrast to the previous 'hourglass' corset, which focussed on whittling the waist. Kortsch notes that although this new style of corset was '[o]stensibly a healthier version of the earlier hourglass", it 'actually produced more ill effects and allowed women to lace to even smaller waist sizes ${ }^{84}$ Valerie Steele confirms the

\footnotetext{
${ }^{83}$ EC, 10 February 1904, 'Works', Add. MS. 46793: vol. 18. 'Entre sein' translates as 'between the breasts', and is a French term for cleavage.

${ }^{84}$ Kortsch, Dress, p. 69.
} 
artists' opinions on 'La Samothrace': 'Being cut lower on top, the new corset no longer functioned as well to support the breasts, and some women began to wear bust-bodices along with their corsets — a trend which eventually led to the development of the modern brassiere'. ${ }^{85}$ Therefore, this exchange illustrates far more than the poets' and the artists' opinions on cleavage. This playful after-dinner conversation hints at shifts associated with a new phase of modernity and female emancipation (the development of the modern brassiere).

\section{'Will not my Love look fair?': Fashion, Gender and Homoerotic Desire}

But what does Bradley and Cooper's preoccupation with fashion mean for lesbian studies today? Their preference for highly feminine gowns unseats expectations of female masculinity in women who are homoerotically inclined - expectations conditioned by the theories of sexual inversion established during the late nineteenth and early twentieth centuries. Donoghue notes how Bradley and Cooper's friends tended to emphasize the differences between the women in their posthumous descriptive accounts, characterizing one as the 'butch' and the other as the 'femme'. ${ }^{86}$ However, these accounts often disagree over whether Bradley or Cooper was the more 'masculine' or 'feminine' of the pair. Rather than revealing any significant truths about the gendered dynamics of Bradley or Cooper's relationship, these accounts instead reflect the increasing urge to categorise intimate same-sex relationships through the lens of modern sexology.

To an extent, studies of lesbian and gay history in the twentieth century tended to perpetuate (if unwittingly) these earlier theories of sexual inversion, by looking for recognizable models of such identities in the historical past. Though such historiographical reclamation has

\footnotetext{
85 Valerie Steele, The Corset: A Cultural History (New Haven: Yale University Press, 2001), p. 84.

${ }^{86}$ Donoghue, Michael Field, p. 33.
} 
unearthed rich and necessary material, historians such as Valerie Traub have criticised the limits of tracing such a genealogy, which tends to find only the 'lesbian types' it was looking for in the first place:

an implicit typological impulse has framed our efforts to render female-female desires intelligible — both in their own historical terms, and in ours. [...] To the extent that [such studies] precipitate the establishment of temporal patterns of meaning-making, they have become complicit in framing historical investigation as an inquiry into an already constituted object. ${ }^{87}$

Judith Halberstam concurs that 'many contemporary lesbian historians cannot extricate themselves from contemporary understandings of lesbian identity long enough to interpret the vagaries of early same-sex desire ${ }^{88}$ In other words, certain configurations of same-sex desire and gender identity can 'slip through the cracks' of such limited historical analysis. ${ }^{89}$

These approaches to lesbian history are relevant when discussing Bradley and Cooper's gender presentation and dress. The importance of fashion to Bradley and Cooper's personal relationship, and to their sense of poetic identity, has been overlooked — perhaps because such a feminine concern appears at odds with the homoerotic nature of their relationship. The women wrote several diary entries and poems in praise of the other's beauty, particularly when a new gown arrived. For example, when Cooper received a new gown in 1892, Bradley observes:

\footnotetext{
${ }^{87}$ Valerie Traub, 'The Present Future of Lesbian Historiography', A Companion to Lesbian, Gay, Bisexual, Transgender, and Queer Studies, eds. George Haggerty and Molly McGarry (Oxford: Blackwell, 2007), 124-145 (p. 127, 135).

${ }^{88}$ Judith Halberstam, Female Masculinity (Durham: Duke University Press, 1998), p. 50.

${ }^{89}$ Traub, 'Lesbian Historiography', p. 128.
} 
Last night came home my Love's new clothes. What a deep interest attaches to them clothes from the first skin coats to the latest gossamer. And my Love has a gown as lustrous as the Lady-Cow; a burnished darkness - in relief are knots of colour that glitter as the cherry. All this to frame the limpid water-tints of her complexion; and her hair the the pencilled springing hair. ${ }^{90}$

This entry is immediately followed by a poem, also in Bradley's hand, the first stanza of which is below:

Will not my Love look fair?

For she has a gown

As lustrous - as the lovely coat

Of the lady-cow

The burnished darkness, the damask notes

That mingle, I know not how,

In a black-green myrtle \& brown;

With a cherry-Rust underneath the chin,-

The limpid, water-tints of her skin

And the pencilled springing hair -

Oh will not my Love look fair! ${ }^{91}$

The following month, Cooper praises another dress: 'Sim's wedding-gown of soft anemone-pink [...] enough to cause a broach of promise of marriage'. ${ }^{92}$ From these examples, we can observe

\footnotetext{
${ }^{90}$ KB, 21 February 1892, 'Works', Add. MS. 46780: vol. 5.

${ }^{91}$ KB, 21 February 1892, 'Works', Add. MS. 46780: vol. 5.

${ }^{92}$ EC, 30 March 1892, 'Works', Add. MS. 46780, vol. 5.
} 
that the admiring gaze works both ways; it is shared and swapped between the two women, as Bradley and Cooper take it in turns to praise the other as desirable muse. Such instances from the diary therefore reveal that, unlike the classic gendered dynamic of the gaze traced by film theorist Laura Mulvey — in which women perform the role of 'object of the gaze', connoting 'to-be-looked-at-ness', and man is encoded as the 'bearer of the gaze' - in Bradley and Cooper's dynamic, these gendered roles are not fixed, but fluid and flexible. ${ }^{93}$ Thus, as Hilary Fraser observes, Michael Field reconstruct the 'unified monocular gaze of the heterosexual male' into a 'binocular look of two women, enacting lesbian desire'. ${ }^{94}$

Evidence from 'Works and Days' therefore attests to the mobility of the objectifying gaze as it passed between the women. Both Bradley and Cooper self-consciously revelled in femininity by dressing in elaborate gowns, actively inviting the gaze of the other. The desire at play here is narcissistic, in the sense that pleasure is derived from seeing one self reflected in the other. Though his work tends to focus on male-male intimacy, Leo Bersani's observations on narcissism provide a useful psychoanalytic framework that can help us understand the centrality of the gaze to Michael Field's homoerotic relationship. Bersani describes such a dynamic as one of 'erotic reciprocity' in which the beloved falls in love with 'the lover's image of him'. ${ }^{95}$ Rather than a destructively ego-bound narcissism, which seeks to incorporate objects outside the self, this narcissistic recognition is relational, ultimately undoing-as Bersani observes-'the opposition between the active lover and the passive loved one [...] the very opposition between sameness and difference becomes irrelevant'. ${ }^{96}$

\footnotetext{
${ }^{93}$ Laura Mulvey, 'Visual Pleasure and Narrative Cinema' (1975), in Literary Theory: An Anthology, eds. Julie Rivkin and Michael Ryan (Oxford: Blackwell, 2001) 585-95 (p. 589).

${ }^{94}$ Hilary Fraser, 'A Visual Field: Michael Field and the Gaze', Victorian Literature and Culture, 34.2 (2006), 553-571 (p. 554).

${ }^{95}$ Leo Bersani and Adam Phillips, Intimacies (Chicago: Chicago University Press, 2008), p. 83.

${ }^{96}$ Bersani, Intimacies, p. 86.
} 
A similar kind of gaze can be identified in nineteenth-century culture, in a rather unexpected source: women's fashion plates. Sharon Marcus argues that Victorian fashion illustrations can be read as a site of the mobile exchange of the female homoerotic gaze:

Produced by women, for women, fashion plates solicited a female gaze for images that put women, their bodies, and the objects that adorned them on display. [...] A woman who looked at a Victorian fashion plate did not simply find her mirror image, for in that plate she saw not one woman but two. Fashion plates reflected her gaze itself, for in most, one woman stares at another who does not directly return her look. The woman who looked at fashion plates thus saw an image of a woman who, like herself, was able to gaze unobserved at a desirable vision of fashionable femininity. ${ }^{97}$

In this sense, these fashion plates not only encouraged the female consumer's gaze but also encoded it within the pictures themselves. A comparable gaze is played out in Bradley and Cooper's diary entries. The praise poems and diary descriptions cited above demonstrate that Bradley and Cooper expressed and performed desire for one another, and shared the roles of subject and object. If neither wore gowns, this mutually pleasurable exchange of the gaze could not take place. This final point recalls Marion Thain's argument that their collaborative pseudonym allowed them to exchange the roles of poet and muse:

Michael Field's dual authorship enables Bradley and Cooper to bypass the problems of poetic identity faced by many women poets of the time by allowing an approach to the

\footnotetext{
${ }^{97}$ Sharon Marcus, Between Women: Friendship, Desire, and Marriage in Victorian England (Princeton: Princeton University Press, 2007), p. 119-121.
} 
lyric that inscribes uncompromised authorial presence. [...] Michael Field's poems are at once by both women and to each other. Both are poet and muse. ${ }^{98}$

In this way, Thain argues, Bradley and Cooper overcome a potential problem facing women poets; that of becoming struck in the position of silent muse — women's conventional role in male-dominated poetic tradition. The women's desire for one another means that the muse comes to represent both self and desired other. For example, in the poem 'A girl' — often used to demonstrate Bradley and Cooper's shared poetic voice — the speaker invites the beloved to complete the poem: 'The work begun/ Will be to heaven's conception done, / If she come to it'. ${ }^{99}$ Holly Laird observes that, rather than being addressed by the poet-subject to the museobject, this lyric is 'instead structured as an invitation to gaze together at each other $[\ldots]$ The poem invites us to be each other's objects'. ${ }^{100}$

As a final note to end on, following their conversion to Catholicism in 1908, Bradley and Cooper continued to use dress to assert their role as artists, and to express and celebrate their love for one another. In 1912, when Edith Cooper was dying of cancer, she and Bradley underwent their confirmation in the Catholic Church. Following the ceremony, Cooper wrote in their diary:

I dress freshly for lunch though I have to cover all with my long Rest-Gown. When loving Michael comes up to be dressed, I persuade her to stay as she is, she is so dowered

\footnotetext{
${ }^{98}$ Marion Thain, Michael Field: Poetry, Aestheticism and the Fin de Siècle (Cambridge: Cambridge University Press, 2007), p. 106.

${ }^{99}$ Michael Field, 'A girl', Underneath the Bough (London: George Bell \& Sons, 1893) 68-69 (p. 69).

${ }^{100}$ Holly Laird, Women Coauthors (Urbana and Chicago, Illinois: University of Illinois Press, 2000), p. 25.
} 
with that graciousness of aspect the Greeks held as gift from the wand of a god or goddess. ${ }^{101}$

In this poignant passage, Cooper gains refreshment from admiring her lover's beauty, even if she herself must be attired in a dowdy 'Rest-Gown'. In my view, this diary entry attests to the fact that — even in the face of death - Michael Field continued to express their desire through a mutually-desiring gaze, rooted in the pleasure they found in experimenting with fashion and revelling in femininity.

Sarah Parker

dr.sarah.l.parker@gmail.com

${ }^{101}$ EC, 4 January 1912, Add. MS. 46802: vol. 27. 